\title{
Association of Paper Association of multiple genetic variants with breast cancer susceptibility in the Han Chinese population
}

\author{
Xu Li ${ }^{1,2, *}$, Wenjing Zou ${ }^{3, *}$, Ming Liu ${ }^{4}$, Wei Cao ${ }^{5}$, Yonghong Jiang ${ }^{6}$, Gaili An7, Yuzheng \\ Wang', Shangke Huang ${ }^{1}$, Xinhan Zhao ${ }^{1}$ \\ ${ }^{1}$ Department of Oncology, First Affiliated Hospital, Xi'an Jiatong University, Xi'an, Shannxi 710061, China \\ ${ }^{2}$ Department of The First of Internal Medicine, Tumor Hospital of Shaanxi Province Affiliated Hospital, Medical College of Xi'an \\ Jiao Tong University, Xi'an, Shannxi 710061, China \\ ${ }^{3}$ Department of The Fifth of Internal Medicine, Xi'an No5 Hospital, Xi'an, Shannxi 710082, China \\ ${ }^{4}$ Department of Obstetrics and Gynecology, Second Affiliated Hospital, Xi'an Jiatong University, Xi'an, Shannxi 710003, China \\ ${ }^{5}$ Department of Oncological Surgery, Shaanxi Provincial People's Hospital, Xi'an 710068, China \\ ${ }^{6}$ Department of Oncological Surgery, Weinan Central Hospital, Weinan, Shaanxi 714000, China \\ ${ }^{7}$ Department of Oncology, Shaanxi Provincial People's Hospital, Xi'an 710068, China \\ *The authors are joint first authors \\ Correspondence to: Xinhan Zhao, email: zhaoxinhanjiaoda@163.com \\ Keywords: breast cancer, single nucleotide polymorphism (SNP), case-control study, Chinese population \\ Received: July 27, $2016 \quad$ Accepted: October 19, $2016 \quad$ Published: November 16, 2016
}

\section{ABSTRACT}

We selected 13 tag single nucleotide polymorphisms (tSNPs) to investigate whether they were associated with breast cancer risk in the Chinese Han population. Upon statistical analyses of clinical data from 551 patients and 577 controls, we found that six of the 13 SNPs were associated with breast cancer; namely, rs4973768(Odds ratio $(O R)=1.30,95 \%$ confidence interval $(C I)=1.01-1.67), r s 981782(O R=1.30$, $95 \% \mathrm{CI}=1.01-1.66), \mathrm{rs} 1432679(\mathrm{OR}=0.84,95 \% \mathrm{CI}=0.70-0.99), \mathrm{rs10759243}(\mathrm{OR}=1.30$, $95 \% C I=1.09-1.55)$, rs10822013(OR $=1.18,95 \% \mathrm{CI}=1.00-1.39)$ and $r s 704010$ (OR $=1.63,95 \% \mathrm{CI}=1.04-2.56)$. When stratified based on breast cancer subtype, our analyses revealed that three SNPs (rs981782, rs10759243 and rs704010) correlated with ER+ breast cancer, while another three (rs4973768, rs1432679 and rs10822013) correlated with ER- breast cancer. We obtained similar results while investigating the correlation of SNPs with PR status or clinical stage. Our results suggest that associations identified between SNPs and breast cancer through genome-wide association studies (GWAS) may not always be generalizable across races.

\section{INTRODUCTION}

Of all the cancers types, breast cancer is leading to the highest incidence and mortality rate in Europe [1] and accounts for $\sim 23 \%$ of new cancer cases as well as $\sim 14 \%$ of cancer-related death [2]. The cause of etiology it is not clear, studying suggested that breast cancer(BC) is a complex disease. Recently, single nucleotide polymorphisms (SNP) in some key loci genetic variations can lead to differences in BC susceptibility between persons. But, most genomewide association studies (GWAS) focused on women of European ancestry. Since the minor allele frequencies and the linkage disequilibrium patterns of the SNP loci were significantly different in different ethnicities, performing
GWAS in populations of different racial descent could help to determine whether previous conclusions regarding the association between SNPs and breast cancer susceptibility are generalizable. Recently, for take disease heterogeneity into account following GWAS analyses, the GWAS-MPE (molecular pathological epidemiology) method was raised $[3,4]$. This approach may provide causal link between risk variants and molecular signatures in diseased cells, thereby allowing to estimate risk for each molecular subtype more precisely and to identify new variant-subtype relationships.

$\mathrm{BC}$ is a heterogeneous cancer in which different risk factors may be leading to different tumor subtypes and that performanced different biological behaviors and progression. Indeed, $\mathrm{BC}$ hormone receptor status 
and pathologic features of cancer affect risk factors. For example, common genetic variants with estrogen receptor (ER + and ER -) breast cancer differences related to support ER + and ER - diseases caused by different etiology way hypothesis [5-7]. Estrogen receptor (ER) and progesterone receptor (PR) are the most commonly used biomarkers for breast cancer subtyping. However, different intrinsic subtypes have significantly in incidence, survival and response to therapy [8, 9]. Since different subtypes of the tumor, the risk of breast cancer is not the same, here we evaluated breast cancer patients in China for 13 SNPs recently identified from GWAS. Namely, we evaluationed the associations of the SNPs with BC ER status, PR status and Clinic stage.

\section{RESULTS}

The 551 BC cancers and 577 normal personss the basic information were listed in Table 1, in Table S1 we listed the MAF of all SNP, stratified by ER and PR status and Table S3 we listed the MAF of all SNP, stratified by Clinic stage. However, the cases BMI were significantly lower than the normal groups ( $p=0.027$ ). We carried out the correction for age and BMI in the follow-up multivariate logistic regression analyses. The study found that one locus (rs1432679, $p=0.043$ ) in the $E B F 1$ gene, another one (rs10759243, $p=0.012$ ) in the KLF4-RPL36AP6 gene, and yet another (rs10822013, $p=0.046)$ in $Z N F 365$ gene were association with breast cancer based on $\chi 2$ tests (Table 2).

We also performed other genetic models analyzed on the relationship between SNPs and BC risk (Table 3). We observed that the minor alleles of rs10759243, rs4973768, rs981782 and rs704010 were associated with breast cancer risk. In the codominant model of rs10759243, the genotype " $\mathrm{C} / \mathrm{A}$ " and "A/A" increased $\mathrm{BC}$ risk by 1.45 -fold $(\mathrm{OR}=$ 1.45; 95\% CI, 1.08-1.94; $p=0.01), 1.65$-fold (OR = 1.65; 95\% CI, 1.15-2.37; $p=0.01$ ), respectively, "C/A-A/A" genotype in the dominant model (OR, 1.50; $95 \% \mathrm{CI}, 1.14-$ $1.98 ; p=0.0035)$. Additionally, the genotypes " $\mathrm{C} / \mathrm{T}-\mathrm{T} / \mathrm{T}$ " of rs4973768 (OR = 1.30; 95\% CI, 1.01-1.67; $p=0.041)$ and "G/T-G/G" of rs981782 indicated an increased the BC risk in the dominant model $(\mathrm{OR}=1.30,95 \% \mathrm{CI}, 1.01-1.66, p$ $=0.043$ ). Meanwhile, the genotype "A/A" of rs704010 may increase breast cancer risk in the recessive model $(\mathrm{OR}=$ $1.63,95 \%$ CI, $1.04-2.56, p=0.033$ ).

\section{Association between SNPs and ER status}

SNPs rs10759243 in the KLF4 gene $(\mathrm{OR}=1.333$, $95 \%$ CI, $1.090-1.629, p=0.005)$, rs704010 in the ZMIZ1 gene $(\mathrm{OR}=1.304,95 \% \mathrm{CI}, 1.053-1.614, p=$ $0.015)$ are associated with an increased the $\mathrm{ER}+\mathrm{BC}$ risk (Supplementary Table S2). We also found an increased risk of ER+ breast cancer For SNP rs10759243 $(P<0.003$ for all analyses except the recessive model) with the highest OR equal to $1.88(1.24-2.86)$ for the "A/A" genotype in the codominant model (Supplementary Table S5). Similarly, SNP rs704010 was observed $(P<0.002$ for all analyses except the dominant model) with the highest $\mathrm{OR}$ equal to $2.08(1.25-3.45)$ for the " $\mathrm{A} / \mathrm{A}$ " genotype in the codominant model. Although no significant association was observed between rs981782 in the NCN1 gene and ER+ breast cancer risk in allelic model analysis, this SNP showed a strong association with ER positive cancer in genetic models.

The SNPs rs4973768 in the SLC4A7 gene (OR = $1.442,95 \%$ CI, $1.075-1.934, p=0.014)$ and $\mathrm{rs} 10822013$ in the $Z N F 365$ gene $(\mathrm{OR}=1.313,95 \% \mathrm{CI}, 1.008-1.710$, $p=0.043$ ) were associated with the risk of ER- BC (Supplementary Table S2). In genetic model analyses, rs4973768 may increase ER- breast cancer risk ( $p=0.022)$ in the dominant model of the " $\mathrm{C} / \mathrm{T}-\mathrm{T} / \mathrm{T}$ " genotype and $(p$ $=0.016$ ) in the additive model (Supplementary Table S6). Furthermore, rs10822013 may increase ER- breast cancer risk ( $p=0.035)$ in the additive model. However, The SNP rs1432679 in the EBF1 gene reduced the ER- BC risk(OR $=0.737,95 \%$ CI $, 0.553-0.980, p=0.036)$ and in the logadditive model $(p=0.043)$.

\section{Association between SNPs and PR status}

We identified an increased the risk of $\mathrm{PR}+\mathrm{BC}$ for SNP rs10759243 $(P<0.002$ for all analyses except the recessive model) with the highest $\mathrm{OR}$ equal to 1.65 (1.05-2.58) for the "A/A" genotype in the codominant model (Supplementary Table S2). The SNP rs704010 in the ZMIZ1 gene was associated with an increased the risk of $\mathrm{PR}+\mathrm{BC}(\mathrm{OR}=1.288,95 \% \mathrm{CI}, 1.028-1.615, p=$ 0.028 ), in the dominant model (OR of 1.38 (1.02-1.87), $p$ $=0.037)$ for the genotype $\mathrm{G} / \mathrm{A}-\mathrm{A} / \mathrm{A}$ and in the log-additive model (OR of 1.32(1.04-1.67), $p=0.024$ ) (Supplementary Table S7). Although we found no association between the rs981782 SNP in the NCN1 gene and $\mathrm{PR}+\mathrm{BC}$ risk in allelic model analysis, the results indicated that this SNP was associated with PR positive cancer $(p=0.02$ for the dominant model, with an OR of 1.44) for the genotype G/T-G/G.

The SNP rs 1432679 in the $E B F 1$ gene reduced the risk of $\backslash \mathrm{PR}$ - $\mathrm{BC}$ risk $(\mathrm{OR}=0.715,95 \% \mathrm{CI}, 0.553-0.925, p$ $=0.010)$ and in the codominant model (OR of $0.52(0.28-$ $0.96), p=0.047$ ) for the genotype T/T (Supplementary Table S8), as well as in the dominant model (OR of 0.68 $(0.48-0.95), p=0.026)$ for the genotype $\mathrm{T} / \mathrm{C}-\mathrm{T} / \mathrm{T}$ and the log-additive model (OR of $0.72(0.56-0.94), p=0.014)$. The SNP rs10759243 in the KLF4 gene was associated with the $\mathrm{PR}-\mathrm{BC}$ risk $(\mathrm{OR}=1.315,95 \% \mathrm{CI}, 1.036-1.671$, $p=0.024)$ and in the log-additive model $(\mathrm{OR}=1.33,95 \%$ CI, $1.04-1.68, p=0.021$ ).

\section{Association between SNPs and clinical stage}

The SNP rs1432679 in the EBF1 gene provided a protective effect in terms of clinical stage (UICC) I and 
Table 1: Clinical characteristics and Disease characteristics of the case-control study population

\begin{tabular}{lccccc}
\hline Variables & $\mathbf{n}$ & Case (\%) & $\mathbf{n}$ & Control (\%) & P \\
\hline Age & 551 & $49.09 \pm 11.022$ & 577 & $48.79 \pm 8.294$ & $0.613^{\mathrm{a}}$ \\
BMI & 459 & $22.52 \pm 2.837$ & 549 & $22.95 \pm 3.214$ & $0.027^{\mathrm{b}}$ \\
Estrogen receptor (ER) status & & & & \\
Positive & 292 & 53 & & \\
Negative & 136 & 24.7 & & \\
Unknown & 123 & 22.3 & & \\
Progesterone receptor (PR) status & & & & \\
Positive & 247 & 44.8 & & \\
Negative & 180 & 32.7 & & \\
Unknown & 124 & 22.5 & & \\
Clinic stage(UICC) & & & & \\
1-2 & 348 & 63.2 & & \\
3-4 & 148 & 26.9 & & \\
Unknown & 55 & 10 & & \\
\hline
\end{tabular}

aP value was calculated by Welch's t test, $\mathrm{p}<0.05$ indicates statistical significance.

bP value was calculated by Student's t test, $\mathrm{p}<0.05$ indicates statistical significance.

Table 2: Allele frequencies in cases and controls and odds ratio estimates for breast cancer

\begin{tabular}{|c|c|c|c|c|c|c|c|c|c|}
\hline \multirow{3}{*}{ SNP } & \multirow{3}{*}{ Gene (s) } & \multirow{3}{*}{ position } & \multicolumn{3}{|l|}{ Alleles } & \multirow{3}{*}{ p-HWE } & \multirow[b]{3}{*}{ Rs } & \multirow[b]{3}{*}{$95 \%$ CI } & \multirow{3}{*}{$P$} \\
\hline & & & $\mathbf{A} / \mathbf{B}$ & & & & & & \\
\hline & & & & Case & Control & & & & \\
\hline rs4849887 & LINC01101-GLI2 & 121245122 & $\mathrm{~T} / \mathrm{C}$ & 0.200 & 0.800 & 0.889 & 1.138 & $0.92-1.40$ & 0.225 \\
\hline rs6762644 & ITPR1 & 4742276 & G/A & 0.090 & 0.910 & 0.805 & 0.991 & $0.75-1.32$ & 0.951 \\
\hline rs4973768 & SLC4A7 & 27416013 & $\mathrm{~T} / \mathrm{C}$ & 0.250 & 0.750 & 0.906 & 1.131 & $0.93-1.37$ & 0.212 \\
\hline rs981782 & $\mathrm{HCN} 1$ & 45285718 & $\mathrm{G} / \mathrm{T}$ & 0.354 & 0.646 & 0.341 & 1.163 & $0.98-1.38$ & 0.088 \\
\hline rs16886165 & RPL26P19-MAP3K1 & 56023083 & $\mathrm{G} / \mathrm{T}$ & 0.312 & 0.688 & 0.925 & 0.940 & $0.79-1.12$ & 0.489 \\
\hline rs889312 & RPL26P19-MAP3K1 & 56031884 & $\mathrm{~A} / \mathrm{C}$ & 0.504 & 0.496 & 0.741 & 1.025 & $0.87-1.21$ & 0.769 \\
\hline rs 1432679 & EBF1 & 158244083 & $\mathrm{~T} / \mathrm{C}$ & 0.325 & 0.675 & 0.929 & 0.836 & $0.70-0.99$ & $0.043 *$ \\
\hline rs2180341 & RNF146 & 127600630 & $\mathrm{G} / \mathrm{A}$ & 0.260 & 0.740 & 0.514 & 1.007 & $0.83-1.22$ & 0.944 \\
\hline rs 10759243 & KLF4 - RPL36AP6 & 110306115 & $\mathrm{~A} / \mathrm{C}$ & 0.476 & 0.524 & 0.270 & 1.238 & $1.05-1.46$ & $0.012 *$ \\
\hline rs 10822013 & ZNF365 & 64251977 & $\mathrm{~T} / \mathrm{C}$ & 0.488 & 0.512 & 0.933 & 1.182 & $1.00-1.39$ & $0.046^{*}$ \\
\hline rs704010 & ZMIZ1 & 80841148 & $\mathrm{~A} / \mathrm{G}$ & 0.320 & 0.680 & 0.052 & 1.185 & $0.99-1.42$ & 0.062 \\
\hline rs 10771399 & PTHLH - CCDC91 & 28155080 & G/A & 0.181 & 0.819 & 0.884 & 1.063 & $0.86-1.32$ & 0.579 \\
\hline rs 17356907 & USP44-PGAM1P5 & 96027759 & $\mathrm{G} / \mathrm{A}$ & 0.230 & 0.770 & 0.820 & 0.947 & $0.78-1.15$ & 0.582 \\
\hline
\end{tabular}

A/B: Minor/major alleles on the control sample; ${ }^{*} p$ value $\leq 0.05$ indicates statistical significance; HWE, Hardy-Weinberg Equilibrium; ORs, odds ratios. 
Table 3: Logistic regression analysis of the association between the SNPs and breast cancer risk

\begin{tabular}{|c|c|c|c|c|c|c|c|c|}
\hline SNP & Model & Genotype & Control & Case & OR(95\%CI) & P-value & AIC & BIC \\
\hline \multirow[t]{8}{*}{ rs4973768 } & & $\mathrm{C} / \mathrm{C}$ & $329(59.9 \%)$ & $246(53.6 \%)$ & 1.00 & & & \\
\hline & Codominant & $\mathrm{C} / \mathrm{T}$ & $194(35.3 \%)$ & $190(41.4 \%)$ & $1.31(1.01-1.70)$ & 0.12 & 1389.8 & 1414.4 \\
\hline & & $\mathrm{T} / \mathrm{T}$ & $26(4.7 \%)$ & $23(5 \%)$ & $1.21(0.67-2.17)$ & & & \\
\hline & Dominant & $\mathrm{C} / \mathrm{C}$ & $329(59.9 \%)$ & $246(53.6 \%)$ & 1.00 & & & \\
\hline & & $\mathrm{C} / \mathrm{T}-\mathrm{T} / \mathrm{T}$ & $220(40.1 \%)$ & $213(46.4 \%)$ & $1.30(1.01-1.67)$ & 0.041 & 1387.9 & 1407.6 \\
\hline & Recessive & $\mathrm{C} / \mathrm{C}-\mathrm{C} / \mathrm{T}$ & $523(95.3 \%)$ & $436(95 \%)$ & 1.00 & & & \\
\hline & & $\mathrm{T} / \mathrm{T}$ & $26(4.7 \%)$ & $23(5 \%)$ & $1.08(0.61-1.93)$ & 0.79 & 1392 & 1411.7 \\
\hline & Log-additive & --- & --- & --- & $1.22(0.98-1.50)$ & 0.069 & 1388.8 & 1408.5 \\
\hline \multirow[t]{8}{*}{ rs 10759243} & & $\mathrm{C} / \mathrm{C}$ & $190(34.7 \%)$ & $119(26.6 \%)$ & 1.00 & & & \\
\hline & Codominant & $\mathrm{C} / \mathrm{A}$ & $257(46.9 \%)$ & $228(50.9 \%)$ & $1.45(1.08-1.94)$ & 0.01 & 1365.6 & 1390.1 \\
\hline & & $\mathrm{A} / \mathrm{A}$ & $101(18.4 \%)$ & $101(22.5 \%)$ & $1.65(1.15-2.37)$ & & & \\
\hline & Dominant & $\mathrm{C} / \mathrm{C}$ & $190(34.7 \%)$ & $119(26.6 \%)$ & 1.00 & 0.0035 & 1364.3 & 1383.9 \\
\hline & & $\mathrm{C} / \mathrm{A}-\mathrm{A} / \mathrm{A}$ & $358(65.3 \%)$ & $329(73.4 \%)$ & $1.50(1.14-1.98)$ & & & \\
\hline & Recessive & $\mathrm{C} / \mathrm{C}-\mathrm{C} / \mathrm{A}$ & $447(81.6 \%)$ & $347(77.5 \%)$ & 1.00 & 0.083 & 1369.8 & 1389.4 \\
\hline & & $\mathrm{A} / \mathrm{A}$ & $101(18.4 \%)$ & $101(22.5 \%)$ & $1.32(0.96-1.80)$ & & & \\
\hline & Log-additive & --- & --- & --- & $1.30(1.09-1.55)$ & 0.0038 & 1364.4 & 1384.1 \\
\hline \multirow[t]{8}{*}{ rs981782 } & & $\mathrm{T} / \mathrm{T}$ & $263(47.9 \%)$ & $189(41.2 \%)$ & 1.00 & & & \\
\hline & Codominant & $\mathrm{G} / \mathrm{T}$ & $226(41.2 \%)$ & $223(48.6 \%)$ & $1.35(1.04-1.76)$ & 0.078 & 1389 & 1413.6 \\
\hline & & $\mathrm{G} / \mathrm{G}$ & $60(10.9 \%)$ & $47(10.2 \%)$ & $1.08(0.71-1.66)$ & & & \\
\hline & Dominant & $\mathrm{T} / \mathrm{T}$ & $263(47.9 \%)$ & $189(41.2 \%)$ & 1.00 & & & \\
\hline & & $\mathrm{G} / \mathrm{T}-\mathrm{G} / \mathrm{G}$ & $286(52.1 \%)$ & $270(58.8 \%)$ & $1.30(1.01-1.66)$ & 0.043 & 1388 & 1407.7 \\
\hline & Recessive & T/T-G/T & $489(89.1 \%)$ & $412(89.8 \%)$ & 1.00 & & & \\
\hline & & $\mathrm{G} / \mathrm{G}$ & $60(10.9 \%)$ & $47(10.2 \%)$ & $0.93(0.62-1.40)$ & 0.74 & 1392 & 1411.6 \\
\hline & Log-additive & --- & --- & --- & $1.14(0.94-1.38)$ & 0.17 & 1390.2 & 1409.9 \\
\hline \multirow[t]{8}{*}{ rs704010 } & & $\mathrm{G} / \mathrm{G}$ & $273(49.7 \%)$ & $212(46.2 \%)$ & 1.00 & & & \\
\hline & Codominant & $\mathrm{G} / \mathrm{A}$ & $240(43.7 \%)$ & $199(43.4 \%)$ & $1.08(0.83-1.40)$ & 0.088 & 1389.2 & 1413.8 \\
\hline & & $\mathrm{A} / \mathrm{A}$ & $36(6.6 \%)$ & $48(10.5 \%)$ & $1.69(1.06-2.70)$ & & & \\
\hline & Dominant & $\mathrm{G} / \mathrm{G}$ & $273(49.7 \%)$ & $212(46.2 \%)$ & 1.00 & & & \\
\hline & & $\mathrm{G} / \mathrm{A}-\mathrm{A} / \mathrm{A}$ & $276(50.3 \%)$ & $247(53.8 \%)$ & $1.16(0.91-1.49)$ & 0.24 & 1390.7 & 1410.4 \\
\hline & Recessive & G/G-G/A & $513(93.4 \%)$ & $411(89.5 \%)$ & 1.00 & & & \\
\hline & & $\mathrm{A} / \mathrm{A}$ & $36(6.6 \%)$ & $48(10.5 \%)$ & $1.63(1.04-2.56)$ & 0.033 & 1387.6 & 1407.2 \\
\hline & Log-additive & --- & --- & --- & $1.20(0.99-1.46)$ & 0.065 & 1388.7 & 1408.4 \\
\hline
\end{tabular}

$P$ : adjusted by Age and BMI; AIC: Akaike's Information criterion; BIC: Bayesian Information criterion.

$* p$ value $\leq 0.05$ indicates statistical significance.

II $\mathrm{BC}(\mathrm{OR}=0.803,95 \% \mathrm{CI}, 0.658-0.980, p=0.031)$ (Supplementary Table S4). On the other hand, genetic models showed no association with clinical stage (UICC) I and II cancer. The SNPs rs 10759243 in the KLF4 gene $(\mathrm{OR}=1.284,95 \% \mathrm{CI}, 1.061-1.552, p=0.010)$ and rs704010 in the $Z M I Z 1$ gene $(\mathrm{OR}=1.237,95 \% \mathrm{CI}, 1.010$ $-1.515, p=0.040)$ were associated with the risk of clinical stage (UICC) I and II breast cancer compared with normal controls (Supplementary Table S9). Such increased risk for the variant rs10759243 in the KLF4 gene was confirmed in 
all the analyses, with the highest OR equal to 1.74 (1.172.61) for the "A/A" genotype in the codominant model. For SNP rs704010, the genotype "A/A" increased clinical stage (UICC) I and II breast cancer risk by 1.90 -fold (OR $=1.90 ; 95 \% \mathrm{CI}, 1.15-3.15 ; p=0.042)$ in the codominant model and 1.88 -fold $(\mathrm{OR}=1.88 ; 95 \% \mathrm{CI}, 1.15-3.05 ; p=$ $0.031)$ in the recessive model.

For SNP rs981782 in the HCN1 gene, the genotype "G/T" increased clinical stage (UICC) III and IV breast cancer risk by 1.83 -fold $(\mathrm{OR}=1.83 ; 95 \% \mathrm{CI}, 1.20-2.80$; $p=0.063)$ in the codominant model and " $\mathrm{G} / \mathrm{T}-\mathrm{G} / \mathrm{G}$ " genotype in the dominant model ( $\mathrm{OR}=1.62 ; 95 \% \mathrm{CI}$, 1.08-2.45; $p=0.019$ ) (Supplementary Table S4).

For SNP rs10759243 in the KLF4 gene, the genotype "C/A" increased clinic stage (UICC) III and IV breast cancer risk by 1.85 -fold $(\mathrm{OR}=1.85 ; 95 \% \mathrm{CI}$, $1.14-3.00 ; p=0.037)$ in the codominant model and " $\mathrm{C} / \mathrm{A}-$ A/A" genotype in the dominant model (OR $=1.79 ; 95 \%$ CI, 1.12-2.85; $p=0.012$ ) (Supplementary Table S10). Additionally, a marginal association $(p=0.05)$ was found between the variant rs4849887 in the LINC01101-GLI2 gene and an increased risk for clinic stage (UICC) III and IV breast cancer in the recessive model, with an OR of 2.39 (1.04-5.46) for the genotype $\mathrm{T} / \mathrm{T}$.

\section{DISCUSSION}

We genotyped 13 tSNPs previously reported to be associated with breast cancer. Our analyses revealedthere have seven SNPswere associated the BC risk. These tSNPs correlated to different degrees with ER/PR status and clinical stage. Our results suggested that these gene polymorphisms may be associated with the risk of BC in Chinese women.

The Kruppel-like factor (KLF) family is a group of transcription factors. And they can control cells of various physiological activities, such as proliferation, apoptosis, inflammation and so on. In particular, the KLF4 gene contributes to maintaining CSCs and promotes migration and invasion, resulting in tumor formation in vivo [10]. KLF4 has been reported to act as both an oncogene and a tumor suppressor in breast cancer [11]. KLF4 specific mechanism we are not yet clear. The SNP rs 10759243 in the KLF4 gene was associated with the risk of $\mathrm{BC}$ in European and Chinese populations [12]. Our study confirmed that SNP rs10759243 was association with $\mathrm{BC}$ in Chinese, in agreement with previous findings. Furthermore, we found that this SNP is also associated with ER+ and PR+ Breast cancer subtypes, consistent with previous results [12].

The transcription factor EBF1 is an interaction partner of the TET2 gene and is involved in the regulation of DNA methylation in a tissue- and sequence-specific mode of IDH1-mutant cancers [13]. In addition, many studies [14, 15] have found mammographic density are associated with $\mathrm{BC}$ risk. The association of SNP rs1432679 (EBF1 gene) with breast cancer appears to correlate with mammographic density phenotypes. Namely, Jennifer Stone's study indicated that the minor "G" allele of rs1432679 is positively association with dense breast tissue and negatively association with nondense tissue, and was positively associated with percent density $(p=1.1 \times 10-5)$. Furthermore, this SNP correlated with increased the $\mathrm{BC}$ risk in Europeans $(\mathrm{OR}=1.06 ; p$ $=0.002$ ) [7]. On the other hand, Zhang Bo's study of the Chinese population showed that rs1432679 provided a protective effect against breast cancer $(\mathrm{OR}=0.98)$ [12]. Our results are consistent with Zhang Bo's research $(\mathrm{OR}=$ $0.836 ; p=0.043$ ). In addition, our research here also found that SNP rs1432679 provided a protective effect against ER- and PR- breast cancer.

The SNP rs704010, lies in the intron 1 of the ZMIZ1 gene, it is encoding zinc finger MIZ-type containing 1 , and regulated the activity of various transcription factors [16]. The androgen receptor (AR) is widespread sex steroid receptor in in situ, invasive, and metastatic BC [17]. Smads are identified proteins that mediate intracellular signaling of TGF- $\beta 1$. TGF $\beta 1$-activated TBX3 protein expression is mediated by $\mathrm{Smad} 3 / 4$ and TBX3 is overexpressed in several cancers, including breast cancer [18]. P53 protein is involved in various cellular processes, such as cell senescence, expression and so on $[19,20]$. The p53 gene expression of correlates with $\mathrm{BC}$ prognosis $[21,22]$. Previously, the SNP rs 704010 in the ZMIZ1 gene was found to correlate with an increased risk of breast cancer $(\mathrm{OR}=1.03)$ and $\mathrm{ER}+\mathrm{BC}(\mathrm{OR}=1.02)$ in women with European ancestry [23]. Turnbull et al. also found rs704010 that the minor allele of " $\mathrm{A}$ "have significantly association with $\mathrm{BC}$ risk (per-allele $\mathrm{OR}=1.38$ for stage 1 ; per-allele $\mathrm{OR}=1.13$ for stage 2 ; Combined $p=3.7 * 10-9$ ) [24].

The SNP rs 2180341 in the RNF146 gene at $6 \mathrm{q} 21.33$ also correlates with the BC risk in Europeans $[25,26]$. However, no significant association was observed in several studies involving Asians [27-30], with the exception of the study by Jun Cheng Dai et al. [31]. Our results for Chinese women were consistent with those from the majority of reports focusing on Asian populations.

The Rs889312 SNP in the RPL26P19-MAP3K1 gene was successfully replicated in Korean women with breast cancer [32]. However, it was not correlates with BC in Chinese women [28, 30, 31, 33, 34], in agreement with our results here.

The rs10822013 SNP at 10q21.2 is located in an intronic region of the zinc finger protein 365 (ZNF365). Qiuyin Cai et al. [35] found among East-Asian women that the $\mathrm{SNP}$ is a risk variant for $\mathrm{BC}$ and the $\mathrm{OR}=1.10$ (95\% CI: 1.07-1.14) $\left(\mathrm{P}=5.87 * 10^{-9}\right)$. Qin Z et al. [36] found that rs10771399 were also associated with BC risk in Asian women. Michcailidou $\mathrm{K}$ et al. recently found the SNP rs4849887 (2q14/INHBB) [37], and which was not evaluated in previous studies of African-American 
women. The rs16886165 SNP, which is close to 3' of the MAP3K1 gene, was foundassociation with breast cancer risk in White women [38].

The other five SNPs we analyzed (rs4849887) LINC01101-GLI2 gene, rs6762644/ITPR1 gene, rs 16886165/RPL26P19-MAP3K1 gene, rs10771399/ PTHLH - CCDC91 gene, rs 17356907/USP44-PGAM1P5 gene) were not correlates with $\mathrm{BC}$ risk in our research. Potential explanations for the difference when compared to previous results could be the effects of other risk factors, or interactions between genes, interactions between genes and the environment, and the effects of LD and the highly variable minor allele frequencies of SNPs in different ethnicities. Our study suffered from other limitations. For example, we only evaluated a limited number of breast cancer associated with risk factors, which did not include age at menarche, age at first live birth and family history of BC. Furthermore, because of our relatively small sample size, body mass index (BMI) was not matched across cases and controls. However, we successfully replicated 13 SNPs from GWAS identified were asscciated with BC in Chinese people breast cancer cases and matched controls. Our study highlight the need to assess the generalizability of previously identified associations between SNPs and $\mathrm{BC}$ and verification is required in different populations.

\section{MATERIALS AND METHODS}

\section{Study population}

A case-control study was conducted to assess genetic associations with breast cancer risk. Eligible cases were those newly diagnosed with breast cancer at the Second Affiliated Hospital, Xi'an Jiatong University, and the Shaanxi Provincial People's Hospital, Xi'an City, China, between June 2012 and Dec 2014. The controls were cancer-free patients randomly recruited from the health centers of the two hospitals during the same study period, and were matched with cases based on age and ethnicity. All cases had histologically confirmed breast cancer. We excluded cases that underwent radiotherapy or chemotherapy as well as controls with chronic disease. All subjects were at least 18 years old and were in good mental condition. Additionally, all of the cases and the controls were genetically unrelated, ethnic Han Chinese women. In total, 577 controls (all female; median age 48.79 \pm 8.294 years) and 551 breast cancer cases (all female; median age $49.09 \pm 11.022$ years) were recruited in this study.

\section{Clinical data and demographic information}

Each participant filled in a standard questionnaire to record demographic information including age, BMI, estrogen receptor (ER), progesterone receptor (PR), clinical stage and family history of cancer. All subjects signed informed consent forms. Blood $(5 \mathrm{ml})$ was collected from each subject according to the study protocol approved by the Clinical Research Ethics Committee of the Second Affiliated Hospital, Xi'an Jiatong University, and the Clinical Research Ethics Committee of the Shaanxi Provincial People's Hospital.

\section{tSNP selection and genotyping}

A SNPs were selected from based on a review of published literature to be associated with Breast Cancer $[7,12,35,36,39-43]$ and with minor allele frequencies (MAF) of $>5 \%$ in the HapMap of the Chinese Han Beijing (CHB) population were selected based on a review of published literature. Genomic DNA was isolated from whole blood samples using the GoldMag-Mini Purification Kit (GoldMag Co. Ltd. Xian city, China). DNA concentrations were measured using the NanoDrop2000 (Thermo Scientific, Waltham, Massachusetts, USA). Sequenom MassARRAY Assay Design 3.0 software was used to design a multiplexed SNP MassEXTENDED assay. A Sequenom MassARRAY mass spectrometry analyzer (Sequenom, San Diego, CA, USA) was used for genotyping and data were managed using Sequenom Typer 4.0 Software (Sequenom, San Diego, CA, USA) [44, 45].

\section{Statistical analyses}

Hardy-Weinberg equilibrium (HWE) was assessed in the control samples by applying an exact test. Deviation from HWE was considered significant at the $P<0.05$ level. Next, the allelic frequencies of each tSNP were compared in cases versus controls using the $\mathrm{x} 2$ test [46]. Finally, the association between each tSNP and breast cancer was assessed under multiple inheritance models using SNPStats, a web-based program available at http://bioinfo.iconcologia.net/snpstats/start.htm [47]. Unconditional logistic regression model adjusted for age and BMI was used to calculate odds ratios (ORs) and 95\% confidence intervals (CI) for each polymorphism. Akaike's information criteria (AIC) and the Bayesian information criteria (BIC) were used to determine the best-fit model for each tSNP. We also analyzed the association between each tSNP and breast cancer after stratification by ER status, PR status and clinical stage to assess whether there was a significant difference in the probability of developing breast cancer under different disease conditions, using the SNP stats software. All statistical tests were two-sided, and a $P$ value equal to or less than 0.05 was considered significant.

\section{ACKNOWLEDGMENTS}

We are grateful to all patients and individuals who participated in this study. We would like to thank clinicians and other hospital staff who contributed to the blood sample and data collection for this study. 


\section{CONFLICTS OF INTEREST}

No conflicts of interest to report.

\section{REFERENCES}

1. Ferlay J, Steliarova-Foucher E, Lortet-Tieulent J, Rosso S, Coebergh JW, Comber H, Forman D, Bray F. Cancer incidence and mortality patterns in Europe: estimates for 40 countries in 2012. European journal of cancer (Oxford, England : 1990). 2013; 49:1374-1403.

2. Jemal A, Bray F, Center MM, Ferlay J, Ward E, Forman D. Global cancer statistics. CA Cancer J Clin. 2011; 61:69-90.

3. Ogino S, Chan AT, Fuchs CS, Giovannucci E. Molecular pathological epidemiology of colorectal neoplasia: an emerging transdisciplinary and interdisciplinary field. Gut. 2011; 60:397-411.

4. Ogino S, Stampfer M. Lifestyle factors and microsatellite instability in colorectal cancer: the evolving field of molecular pathological epidemiology. Journal of the National Cancer Institute. 2010; 102:365-367.

5. Garcia-Closas M, Couch FJ, Lindstrom S, Michailidou K, Schmidt MK, Brook MN, Orr N, Rhie SK, Riboli E, Feigelson HS, Le Marchand L, Buring JE, Eccles D, Miron $\mathrm{P}$, Fasching PA, Brauch $\mathrm{H}$, et al. Genome-wide association studies identify four ER negative-specific breast cancer risk loci. Nature genetics. 2013; 45:392-398, 398e391-392.

6. Lei J, Rudolph A, Moysich KB, Rafiq S, Behrens S, Goode EL, Pharoah PP, Seibold P, Fasching PA, Andrulis IL, Kristensen VN, Couch FJ, Hamann U, Hooning MJ, Nevanlinna H, Eilber U, et al. Assessment of variation in immunosuppressive pathway genes reveals TGFBR2 to be associated with prognosis of estrogen receptor-negative breast cancer after chemotherapy. Breast cancer research. $2015 ; 17: 18$.

7. Long J, Zhang B, Signorello LB, Cai Q, Deming-Halverson S, Shrubsole MJ, Sanderson M, Dennis J, Michailidou K, Easton DF, Shu XO, Blot WJ, Zheng W. Evaluating genome-wide association study-identified breast cancer risk variants in African-American women. PloS one. 2013; 8:e58350.

8. Blows FM, Driver KE, Schmidt MK, Broeks A, van Leeuwen FE, Wesseling J, Cheang MC, Gelmon K, Nielsen TO, Blomqvist C, Heikkila P, Heikkinen T, Nevanlinna H, Akslen LA, Begin LR, Foulkes WD, et al. Subtyping of breast cancer by immunohistochemistry to investigate a relationship between subtype and short and long term survival: a collaborative analysis of data for 10,159 cases from 12 studies. PLoS medicine. 2010; 7:e1000279.

9. Xue C, Wang X, Peng R, Shi Y, Qin T, Liu D, Teng X, Wang S, Zhang L, Yuan Z. Distribution, clinicopathologic features and survival of breast cancer subtypes in Southern China. Cancer science. 2012; 103:1679-1687.
10. Dong MJ, Wang LB, Jiang ZN, Jin M, Hu WX, Shen JG. The transcription factor KLF4 as an independent predictive marker for pathologic complete remission in breast cancer neoadjuvant chemotherapy: a case-control study. OncoTargets and therapy. 2014; 7:1963-1969.

11. Tien YT, Chang MH, Chu PY, Lin CS, Liu CH, Liao AT. Downregulation of the KLF4 transcription factor inhibits the proliferation and migration of canine mammary tumor cells. Veterinary journal (London, England : 1997). 2015; 205:244-253.

12. Zhang B, Li Y, Li L, Chen M, Zhang C, Zuo XB, Zhou FS, Liang B, Zhu J, Li P, Huang ZL, Xuan H, Li W, Chen ZD. Association study of susceptibility loci with specific breast cancer subtypes in Chinese women. Breast cancer research and treatment. 2014; 146:503-514.

13. Zhuang J, Jones A, Lee SH, Ng E, Fiegl H, Zikan M, Cibula D, Sargent A, Salvesen HB, Jacobs IJ, Kitchener HC, Teschendorff AE, Widschwendter M. The dynamics and prognostic potential of DNA methylation changes at stem cell gene loci in women's cancer. PLoS genetics. 2012; 8:e1002517.

14. Aitken Z, McCormack VA, Highnam RP, Martin L, Gunasekara A, Melnichouk O, Mawdsley G, Peressotti C, Yaffe M, Boyd NF, dos Santos Silva I. Screenfilm mammographic density and breast cancer risk: a comparison of the volumetric standard mammogram form and the interactive threshold measurement methods. Cancer epidemiology, biomarkers \& prevention. 2010; 19:418-428.

15. Shepherd JA, Kerlikowske K, Ma L, Duewer F, Fan B, Wang J, Malkov S, Vittinghoff E, Cummings SR. Volume of mammographic density and risk of breast cancer. Cancer epidemiology, biomarkers \& prevention. 2011; 20:1473-1482.

16. Li J, Weinberg MS, Zerbini L, Prince S. The oncogenic TBX3 is a downstream target and mediator of the TGFbeta1 signaling pathway. Molecular biology of the cell. 2013; 24:3569-3576.

17. Hickey TE, Robinson JL, Carroll JS, Tilley WD. Minireview: The androgen receptor in breast tissues: growth inhibitor, tumor suppressor, oncogene? Molecular endocrinology (Baltimore, Md). 2012; 26:1252-1267.

18. Arendt LM, St Laurent J, Wronski A, Caballero S, Lyle SR, Naber SP, Kuperwasser C. Human breast progenitor cell numbers are regulated by WNT and TBX3. PloS one. 2014; 9:e111442.

19. Freed-Pastor WA, Prives C. Mutant p53: one name, many proteins. Genes \& development. 2012; 26:1268-1286.

20. Walerych D, Napoli M, Collavin L, Del Sal G. The rebel angel: mutant p53 as the driving oncogene in breast cancer. Carcinogenesis. 2012; 33:2007-2017.

21. Chiorean R, Braicu C, Berindan-Neagoe I. Another review on triple negative breast cancer. Are we on the right way towards the exit from the labyrinth? Breast (Edinburgh, Scotland). 2013; 22:1026-1033. 
22. Xie YF, Shu R, Jiang SY, Song ZC, Guo QM, Dong JC, Lin ZK. miRNA-146 negatively regulates the production of pro-inflammatory cytokines via NF-kappaB signalling in human gingival fibroblasts. Journal of inflammation (London, England). 2014; 11:38.

23. Han MR, Deming-Halverson S, Cai Q, Wen W, Shrubsole MJ, Shu XO, Zheng W, Long J. Evaluating 17 breast cancer susceptibility loci in the Nashville breast health study. Breast cancer (Tokyo, Japan). 2015; 22:544-551.

24. Turnbull C, Ahmed S, Morrison J, Pernet D, Renwick A, Maranian M, Seal S, Ghoussaini M, Hines S, Healey CS, Hughes D, Warren-Perry M, Tapper W, Eccles D, Evans DG, Hooning M, et al. Genome-wide association study identifies five new breast cancer susceptibility loci. Nature genetics. 2010; 42:504-507.

25. Gold B, Kirchhoff T, Stefanov S, Lautenberger J, Viale A, Garber J, Friedman E, Narod S, Olshen AB, Gregersen P, Kosarin K, Olsh A, Bergeron J, Ellis NA, Klein RJ, Clark AG, et al. Genome-wide association study provides evidence for a breast cancer risk locus at $6 \mathrm{q} 22.33$. Proceedings of the National Academy of Sciences of the United States of America. 2008; 105:4340-4345.

26. Kirchhoff T, Chen ZQ, Gold B, Pal P, Gaudet MM, Kosarin K, Levine DA, Gregersen P, Spencer S, Harlan M, Robson M, Klein RJ, Hudis CA, Norton L, Dean M, Offit K. The 6q22.33 locus and breast cancer susceptibility. Cancer epidemiology, biomarkers \& prevention. 2009; 18:2468-2475.

27. Campa D, Kaaks R, Le Marchand L, Haiman CA, Travis RC, Berg CD, Buring JE, Chanock SJ, Diver WR, Dostal L, Fournier A, Hankinson SE, Henderson BE, Hoover RN, Isaacs $\mathrm{C}$, Johansson $\mathrm{M}$, et al. Interactions between genetic variants and breast cancer risk factors in the breast and prostate cancer cohort consortium. Journal of the National Cancer Institute. 2011; 103:1252-1263.

28. Long J, Shu XO, Cai Q, Gao YT, Zheng Y, Li G, Li C, Gu K, Wen W, Xiang YB, Lu W, Zheng W. Evaluation of breast cancer susceptibility loci in Chinese women. Cancer epidemiology, biomarkers \& prevention. 2010; 19:2357-2365.

29. Zheng W, Cai Q, Signorello LB, Long J, Hargreaves MK, Deming SL, Li G, Li C, Cui Y, Blot WJ. Evaluation of 11 breast cancer susceptibility loci in African-American women. Cancer epidemiology, biomarkers \& prevention. 2009; 18:2761-2764.

30. Zheng W, Wen W, Gao YT, Shyr Y, Zheng Y, Long J, Li G, Li C, Gu K, Cai Q, Shu XO, Lu W. Genetic and clinical predictors for breast cancer risk assessment and stratification among Chinese women. Journal of the National Cancer Institute. 2010; 102:972-981.

31. Dai J, Hu Z, Jiang Y, Shen H, Dong J, Ma H, Shen H. Breast cancer risk assessment with five independent genetic variants and two risk factors in Chinese women. Breast cancer research. 2012; 14:R17.
32. Han W, Woo JH, Yu JH, Lee MJ, Moon HG, Kang D, Noh DY. Common genetic variants associated with breast cancer in Korean women and differential susceptibility according to intrinsic subtype. Cancer epidemiology, biomarkers \& prevention. 2011; 20:793-798.

33. Jiang Y, Han J, Liu J, Zhang G, Wang L, Liu F, Zhang X, Zhao Y, Pang D. Risk of genome-wide association study newly identified genetic variants for breast cancer in Chinese women of Heilongjiang Province. Breast cancer research and treatment. 2011; 128:251-257.

34. Liang J, Chen P, Hu Z, Shen H, Wang F, Chen L, Li M, Tang J, Wang H, Shen H. Genetic variants in trinucleotide repeatcontaining 9 (TNRC9) are associated with risk of estrogen receptor positive breast cancer in a Chinese population. Breast cancer research and treatment. 2010; 124:237-241.

35. Cai Q, Long J, Lu W, Qu S, Wen W, Kang D, Lee JY, Chen K, Shen H, Shen CY, Sung H, Matsuo K, Haiman CA, Khoo US, Ren Z, Iwasaki M, et al. Genome-wide association study identifies breast cancer risk variant at 10q21.2: results from the Asia Breast Cancer Consortium. Human molecular genetics. 2011; 20:4991-4999.

36. Qin Z, Wang Y, Cao S, He Y, Ma H, Jin G, Hu Z, Guan X, Shen $\mathrm{H}$. Genetic variants at $12 \mathrm{p} 11$ and $12 \mathrm{q} 24$ are associated with breast cancer risk in a Chinese population. PloS one. 2013; 8:e66519.

37. Michailidou K, Hall P, Gonzalez-Neira A, Ghoussaini M, Dennis J, Milne RL, Schmidt MK, Chang-Claude J, Bojesen SE, Bolla MK, Wang Q, Dicks E, Lee A, Turnbull C, Rahman N, Fletcher O, et al. Large-scale genotyping identifies 41 new loci associated with breast cancer risk. Nature genetics. 2013; 45:353-361, 361e351-352.

38. Thomas G, Jacobs KB, Kraft P, Yeager M, Wacholder S, Cox DG, Hankinson SE, Hutchinson A, Wang Z, Yu K, Chatterjee N, Garcia-Closas M, Gonzalez-Bosquet J, Prokunina-Olsson L, Orr N, Willett WC, et al. A multistage genome-wide association study in breast cancer identifies two new risk alleles at 1p11.2 and 14q24.1 (RAD51L1). Nature genetics. 2009; 41:579-584.

39. Chen J, Jiang Y, Liu X, Qin Z, Dai J, Jin G, Ma H, Wang $\mathrm{S}$, Wang X, Hu Z, Shen H. Genetic variants at chromosome 9p21,10p15 and 10q22 and breast cancer susceptibility in a Chinese population. Breast cancer research and treatment. 2012; 132:741-746.

40. Loizidou MA, Hadjisavvas A, Ioannidis JP, Kyriacou K. Replication of genome-wide discovered breast cancer risk loci in the Cypriot population. Breast cancer research and treatment. 2011; 128:267-272.

41. Lu PH, Yang J, Li C, Wei MX, Shen W, Shi LP, Jiang ZY, Zhou N, Tao GQ. Association between mitogen-activated protein kinase kinase kinase 1 rs889312 polymorphism and breast cancer risk: evidence from 59,977 subjects. Breast cancer research and treatment. 2011; 126:663-670.

42. Stacey SN, Manolescu A, Sulem P, Thorlacius S, Gudjonsson SA, Jonsson GF, Jakobsdottir M, Bergthorsson 
JT, Gudmundsson J, Aben KK, Strobbe LJ, Swinkels DW, van Engelenburg KC, Henderson BE, Kolonel LN, Le Marchand L, et al. Common variants on chromosome 5p12 confer susceptibility to estrogen receptor-positive breast cancer. Nature genetics. 2008; 40:703-706.

43. Zheng Y, Ogundiran TO, Falusi AG, Nathanson KL, John EM, Hennis AJ, Ambs S, Domchek SM, Rebbeck TR, Simon MS, Nemesure B, Wu SY, Leske MC, Odetunde A, Niu Q, Zhang J, et al. Fine mapping of breast cancer genome-wide association studies loci in women of African ancestry identifies novel susceptibility markers. Carcinogenesis. 2013; 34:1520-1528.

44. Gabriel S, Ziaugra L, Tabbaa D. SNP genotyping using the Sequenom MassARRAY iPLEX platform. Current protocols in human genetics. 2009; Chapter 2:Unit 2.12.
45. Thomas RK, Baker AC, Debiasi RM, Winckler W, Laframboise T, Lin WM, Wang M, Feng W, Zander T, MacConaill L, Lee JC, Nicoletti R, Hatton C, Goyette M, Girard L, Majmudar K, et al. High-throughput oncogene mutation profiling in human cancer. Nature genetics. 2007; 39:347-351.

46. Adamec C. [EXAMPLE OF THE USE OF THE NONPARAMETRIC TEST. TEST X2 FOR COMPARISON OF 2 INDEPENDENT EXAMPLES]. [Article in Czech]. Ceskoslovenske zdravotnictvi. 1964; 12:613-619.

47. Bland JM, Altman DG. Statistics notes. The odds ratio. BMJ (Clinical research ed). 2000; 320:1468. 